\title{
Termites (Isoptera Brullé 1832) of Abuko Nature Reserve, Nyambai Forest Park and Tanji Bird Reserve (The Gambia)
}

\author{
NDIAYE Abdoulaye Baïla ${ }^{1}$, NJIE Ebrima ${ }^{2}$, CORREA Paul ${ }^{2}$ \\ 1. Laboratoire de Zoologie des Invertébrés terrestres, IFAN, UCAD, B. P. 206, Dakar, \\ Sénégal. E-mail: abdoulayeb.ndiaye@ucad.edu.sn (corresponding author) \\ 2. School of Arts and Sciences, Division of Physical and Natural Sciences: University of The \\ Gambia, Brikama Campus P.O. Box 3530, Serekunda, The Gambia
}

\begin{abstract}
From October 28 to November 05, 2013, we conducted a termite sampling in 3 protected sites in The Gambia (West Africa). Termites sampling is carried out in $100 \mathrm{~m} \times 2 \mathrm{~m}$ transects repeated 3 times in each site. A total of 33 species of termites have been recorded. Of the 33 species, 22 are new to The Gambia. Additionnal measurements are given for several collected termite species. Euchilotermes arcuata Silvestri is elevated to the rank of species.
\end{abstract}

Key words: Termites, The Gambia, protected sites

\section{INTRODUCTION}

The termite fauna of The Gambia is still poorly known. One single termite collection trial carried out by Sands in 1966 in the country has been documented [1].

Prior to this date, one termite species, Odontotermes capensis, referred to as Termes fatalis was wrongly reported to The Gambia by Walker in 1845 [2]. The occurrence of T. fatalis in both South Africa and The Gambia is objected to by Sjöstedt [3,4]. The African species referred to as O. capensis is restricted to South Africa and does not occur in The Gambia [5].

Between 1950 and 2013, 30 species of termites listed below have been recorded to The Gambia according to the works of Sands [1, 6, 7, 8]; Williams \& Perez-Morales;-[9], Johnson et al. [10] and Krishna et al. [5].

Kalotermitidae

Cryptotermes brevis (Walker, 1853)

Cryptotermes havilandi (Sjöstedt, 1900)

Rhinotermitidae

Coptotermitinae

Coptotermes sjostedti Holmgren, 1911

Termitidae 
Macrotermitinae

Ancistrotermes crucifer (Sjöstedt, 1897)

Ancistrotermes guineensis (Silvestri, 1912)

Macrotermes subhyalinus (Rambur, 1842)

Megaprotermes giffardii (Silvestri, 1914)

Apicotermitinae

Allognathotermes ivorensis Grassé and Noirot, 1955

Adaiphrotermes cuniculator Sands, 1972

Aderitotermes cavator Sands, 1972

Alyscotermes kilimandjaricus (Sjöstedt, 1907)

Anenteotermes ateuchestes Sands, 1972

Nasutitermitinae

Eutermellus undulans Sands, 1965

Fulleritermes tenebricus (Silvestri, 1914)

Nasutitermes arborum (Smeathman, 1781)

Trinervitermes trinervius (Rambur, 1842).

Cubitermitinae

Basidentitermes aurivillii (Sjöstedt, 1897)

Basidentitermes potens Silvestri, 1914

Cubitermes bilobatodes Silvestri, 1912

Cubitermes gaigei (Emerson, 1928)

Cubitermes proximatus Silvestri, 1914

Cubitermes severus Silvestri, 1914

Euchilotermes tensus tensus Silvestri, 1914

Megagnathotermes notandus Silvestri, 1914

Procubitermes sjostedti (Rosen, 1912)

Trapellitermes loxomastax Sands, 1995

Termitinae

Amitermes guineensis Sands, 1992

Promirotermes redundans Silvestri, 1914

Pericapritermes nigerianus Silvestri, 1914

Pericapritermes urgens Silvestri, 1914 
In the framework collaboration between the Institut Francophone d'Afrique Noire (IFAN) and the Division of Physical and Natural Sciences (University of The Gambia), a termite collection trial was carried out in 2015 from October 28th to November 5 th by a joint team of scientists from the two Institutions in three different sites, namely: Abuko Nature Reserve, Nyambai Forest Park and Tanji Bird Reserve.

\section{MATERIAL AND METHODS}

\section{Study Sites}

The Gambia is a small country in West Africa enclosed by the Senegalese territory (fig. 1). The climate is characterized by a short rainy season from July to September and a dry season the rest of the year. From the coast to the inland, rainfall $(900-1,300 \mathrm{~mm})$ declines and temperatures increase. In dry season, the inland regions have average temperature as high as $35^{\circ} \mathrm{C}$, whilst the average temperature in the coastal regions ranges between $25^{\circ}$ and $28^{\circ} \mathrm{C}$. In wet season, average temperature can be below $25^{\circ} \mathrm{C}$ at the coast and up to $30^{\circ} \mathrm{C}$ in the inland.

The Termites were sampled from the Abuko Nature Reserve, Tanji Bird Reserve and the Nyambai Forest Park, wich are protected areas in the coastal region (fig. 1).

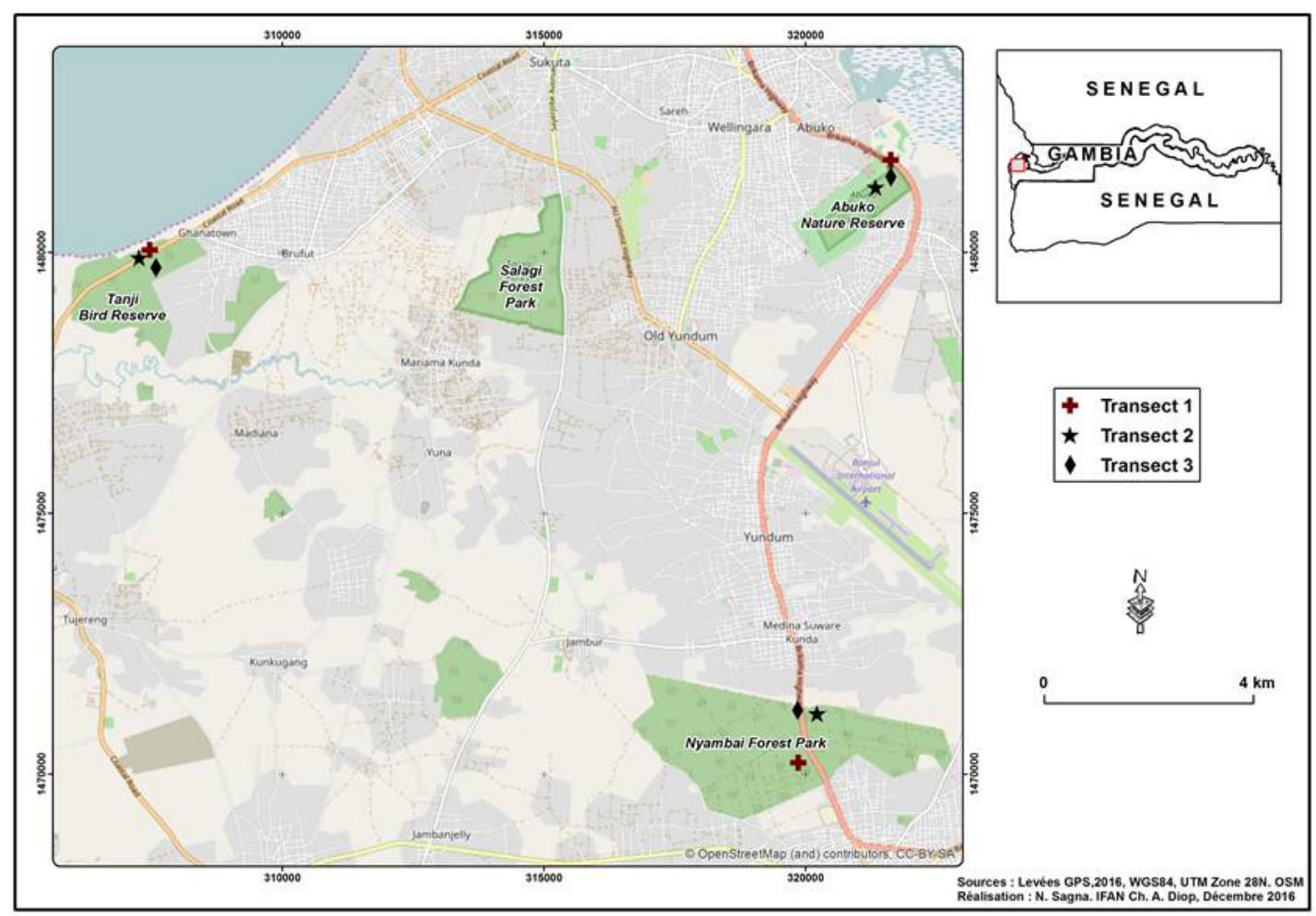

Figure 1. Location of the study sites Abuko Nature Reserve, Tanji Bird Reserve and Nyambai Forest Park 


\section{Abuko Nature Reserve}

The Abuko Nature Reserve is located outside the village of Lamin (13²3'00.45' $\mathrm{N}$, $16^{\circ} 38^{\prime} 37.9^{\prime \prime} \mathrm{W}$ ) in the Kombo North District, about $25 \mathrm{~km}$ away from Banjul. It has been protected as a water catchment area since 1916 and was officially declared a nature reserve in 1968. With a current size of 106 ha, Abuko Nature Reserve is home to a wide diversity of mammals, birds and invertebrates.

Rectangular in shape, the reserve is surrounded by a $300 \mathrm{~m}$ width buffer zone and it is centered on the Lamin village stream which surfaces within the lower half of the reserve, thereby providing a fairly humid microclimate in the heart of the area. The transect locations are shown on the figure 2 .

For most time of the year, the central part of the reserve is very humid due to the presence of a dense gallery forest which surrounds a chain of 3 pools. A dense evergreen forest rises from the water course. Soils are sandy in the periphery of the reserve and sandy/muddy towards the center where the tree canopy forms a continuous shade over the lower vegetation particularly during wet season.

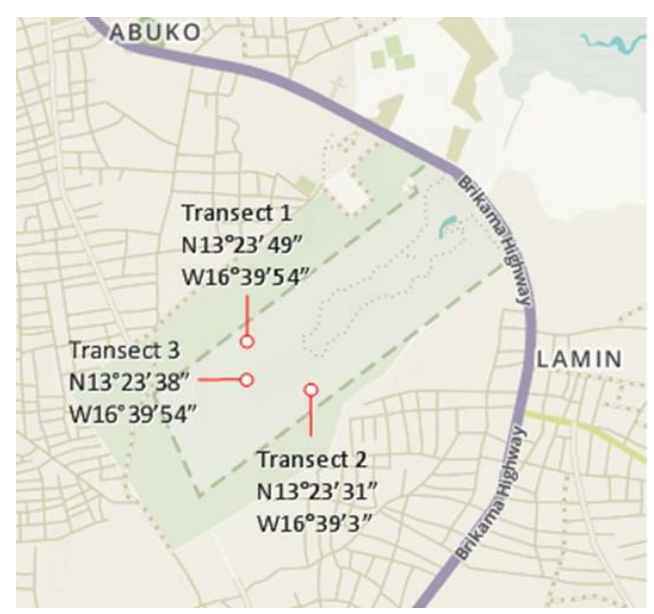

Figure 2. Transects of termite sampling at Abuko Nature Reserve

Abuko Nature Reserve is among the least disturbed natural sites of The Gambia where numerous animal species as well plant species continue to be under strong official conservation measures.

\section{Tanji Bird Reserve}

The Tanji River Bird Reserve is located along the Atlantic Coast, in the Western Division, Kombo North, a few kilometers away from the fishing village Ghana town $\left(13^{\circ} 23^{\prime} 06.67 \mathrm{~N}\right.$, 
$\left.16^{\circ} 46^{\prime} 05.04^{\prime \prime} \mathrm{W}\right)$. The reserve was established in 1993 and covers a surface area of 612 ha $\left(6.12 \mathrm{~km}^{2}\right)$. The three transects locations are shown on the figure 3 .

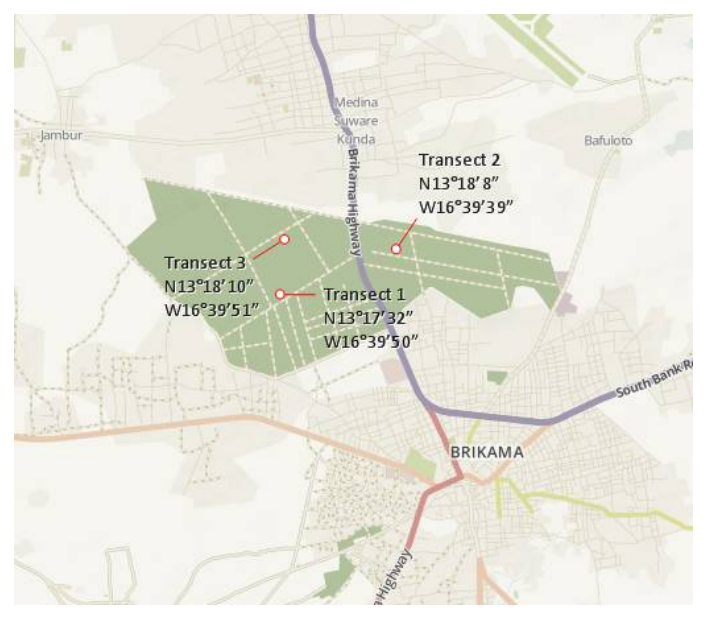

Figure 3. Transects of termite sampling at Tanji Bird Reserve

It encompasses the Tanji River and estuary and includes mangrove ecosystem, dry woodland and coastal dune scrub woodland. Within the Tanji Bird Reserve there is a wide variety of habitat types including marine, estuarine, freshwater, coastal scrub woodland and dry woodland savannah. The climate is greatly influenced by the ocean wind.

The northern strip is denser and has lower canopy height due to previous clearance. The southern strip is more open with isolated mature trees, as a result of long term grazing patterns. The dominant plant species found are the Ginger Bread Plum, Parinari macrophylla, the Rhun Palm, Borassus aethiopium, and the Baobab, Adansonia digitata. The understorey is generally grass dominated by the feathery flowered, Perotis indica, the stiff leafed Sporobolus spicatus and the spiny fruited Cenchrus biflorus. A variety of invertebrates populates the reserve, with arthropods being the most abundant.

\section{The Nyambai Forest}

The Nyambai Forest Park is an artificial forest established in 1964. The park was enriched with Gmelina arborea and Phyllostachys edullus species. It is located at midway between

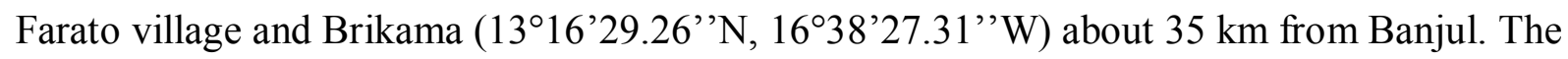
transect locations are shown on the figure 4. 


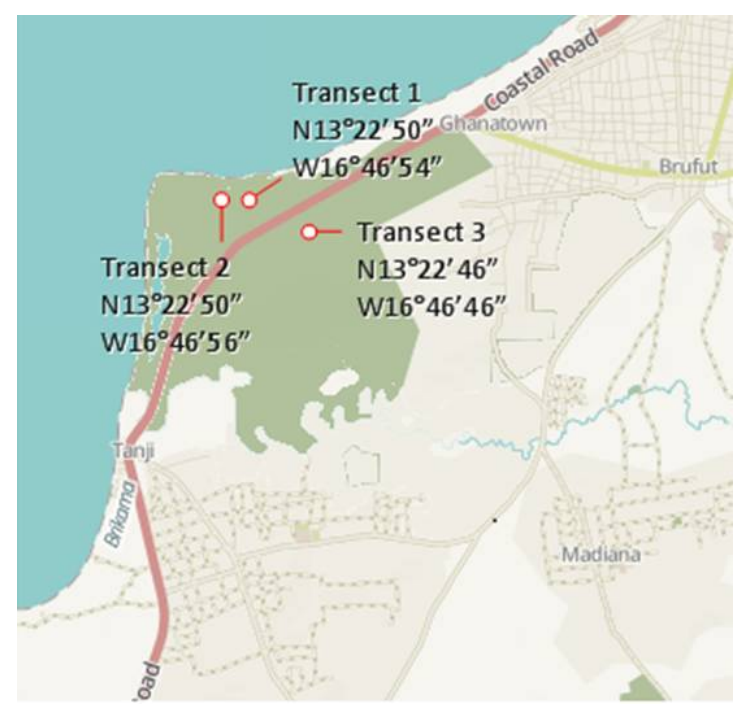

Figure 4. Transects of termite sampling at Nyambai Forest Park

The vegetation of the forest park is essentially composed of three different species: a spiny shrub vegetation, tall but thin Gmelina arborea canopy with a narrow strip of Phyllostachys sp. on the Northen side.

The soil is completely covered with thick layer of litter; few thriving grasses grow here and there on the finely sandy to muddy soil. The relative humidity is high in the morning and late in the evening. Monthly average of temperatures range are between $17-24^{\circ} \mathrm{C}$ for the minima and $31-33^{\circ} \mathrm{C}$ for the maxima.

\section{Sampling Methods}

Within each of these above sites the sampling method, a derivative of Jones \& Eggleton [11] sampling method, was carried out using transect ( 3 transects/site) with $100 \mathrm{~m}$ long and $2 \mathrm{~m}$ wide. The duration of the sampling is not limited but depends on the time required to cover the entire transect. In each transect, a thorough search of termites is carried out in the soil, the litter, the dead wood, in stump of trees, under the bark of trees, and the arboreal termite nests.

The encountered termite soldiers, workers, swarming individuals, kings or queens are collected and kept in ethanol $70 \%$ within labeled containers bearing the name of the site, the date, and the micro-habitat.

\section{Species identification}

Identification begins with a direct observation under the microscope with a comparison, if necessary, of specimens to be identified with reference specimens from the IFAN (Institut 
fondamental d'Afrique noire) collection identified by W. A. Sands and/or with reference works by Silvestri [12, 13], Sjöstedt [3], Emerson [14], Grassé [15, 16], Bouillon \& Mathot [17] and Roy-Noël [18]. The more focused works of Sands for Nasutitermitinae [19] and for the genus Amitermes [20] were also used. Identification of soldierless species of Apicotermitinae has been made after sands $[6,8]$ on the basis of the morphology of the digestive tube: the mesenteron-proctodeum junction and the enteric valves, dissected, are observed under stereomicroscope. For the species of Cubitermes, we used the key of Josens [21] and also consulted Pr. Josens. In addition to the external morphology of the soldiers, workers enteric valves were dissected for species identification.

The head and mandible measurements are:

- head width corresponding to the maximum width in dorsal view;

- head length measured in dorsal view from the occiput to the base of labrum (soldier) or anterior of clypeus (worker),

- length of left mandible measured in dorsal view, from the lateral most proximal visible point to the apical point.

\section{RESULTS}

\section{Termite diversity in the three sites}

Thirty one (31) termite species have been recorded in the three sites. They belong to the following two families, six subfamilies and nineteen genera.

RHINOTERMITIDAE Froggatt, 1897

Coptotermitinae Holmgren, 1910

Coptotermes Wasmann, 1896

Coptotermes intermedius Silvestri, 1912

TERMITIDAE Latreille, 1802

Macrotermitinae Kemner, 1934

Ancistrotermes Silvestri, 1912

Ancistrotermes cavithorax (Sjöstedt, 1899)

Ancistrotermes crucifer (Sjöstedt, 1897)

Ancistrotermes guineensis (Silvestri, 1912)

Macrotermes Holmgren, 1909 
Macrotermes bellicosus (Smeathman, 1781)

Macrotermes subhyalinus (Rambur, 1842)

Microtermes Wasmann, 1902

Microtermes grassei Ghidini, 1955

Microtermes lepidus Sjöstedt, 1924

Microtermes subhyalinus Silvestri, 1914

Odontotermes Holmgren, 1910

Odontotermes erraticus Grassé, 1944

Odontotermes pauperans (Silvestri, 1912)

Odontotermes sudanensis Sjöstedt, 1924

Apicotermitinae Grassé \& Noirot, 1955

Adaiphrotermes Sands, 1972

Adaiphrotermes near cuniculator Sands, 1972

Aderitotermes Sands, 1972

Aderitotermes near cavator Sands, 1972

Astalotermes Sands, 1972

Astalotermes near quietus Sands, 1972

Allognathotermes Silvestri, 1914

Allognathotermes ivorensis Grassé \& Noirot, 1954

Nasutitermitinae Hare, 1937

Nasutitermes Dudley, 1890

Nasutitermes arborum (Smeathman, 1781)

Trinervitermes Holmgren, 1912

Trinervitermes trinervius (Rambur, 1842)

Cubitermitinae Weidner, 1956

Basidentitermes Holmgren, 1912,

Basidentitermes potens Silvestri, 1914

Basidentitermes sp.

Cubitermes Wasmann, 1906

Cubitermes severus Silvestri, 1914

Cubitermes near proximatus Silvestri, 1914

Euchilotermes Silvestri, 1914

Euchilotermes arcuata Silvestri, 1914 
Noditermes Sjöstedt, 1924

Noditermes cristifrons (Wasmann, 1911)

Termitinae Latreille, 1802

Amitermes Silvestri, 1901

Amitermes evuncifer (Silvestri, 1912)

Amitermes spinifer (Silvestri, 1914)

Microcerotermes Silvestri, 1901

Microcerotermes fuscotibialis (Sjöstedt, 1896)

Microcerotermes near parvulus (Sjöstedt, 1911)

Microcerotermes near solidus Silvestri, 1912

Pericapritermes Silvestri, 1914

Pericapritermes urgens Silvestri, 1914

Promirotermes Silvestri, 1914

Promirotermes holmgreni (Silvestri, 1912)

\section{Termites diversity in Abuko Nature Reserve}

At Abuko Nature Reserve, 27 species of termites belonging to 2 families and 5 subfamilies were recorded (table 1). The variable number of collected species between transects in the site (as shown in table 1) suggests a certain heterogeneity of the termite distribution.

In terms of functional diversity, there is predominance of the humivorous termites with 11 species followed by the fungus-growing Macrotermitinae which are represented by 9 species. The xylophagous ( 6 species) and the haverster termites ( 1 species) are the least diverse. This type of termite assemblage in Abuko is characteristic of a forestry profile.

\section{Termites diversity in Nyambai Forest Park}

The species richeness of termites in Nyambai Forest Park is of 20 species (table 2). At functional level, there is still a greater diversity of the humivorous termites represented with 12 species followed by the fungus-growing termite ( 8 species). The harvester termites and the xylophagous termites are represented each by 1 species.

The spatial distribution of the termite species is rather heterogeneous: 12 species are recorded in the station 1, 10 species in station 2 and 16 species in the station 3 . The species richness and spatial distribution heterogeneity in Nyambai Forest are less important than in Abuko and could be associated with the relatively low botanical diversity in this artificial site. 


\begin{tabular}{|c|c|c|c|}
\hline Nasutitermes arborum (Smeathman, 1781) & - & - & Dead wood, tree $(S, W)$ \\
\hline Trinervitermes trinervius (Rambur, 1842) & - & - & Nest $(S, W)$ \\
\hline Basidentitermes potens Silvestri, 1914 & Nest $(S, W)$ & Soil (S, W) & - \\
\hline Basidentitermes sp. & Soil (S, W) & - & - \\
\hline Cubitermes near proximatus Silvestri, 1914 & Nest, Soil (S, W) & Nest (S, W) & - \\
\hline Cubitermes severus Silvestri, 1914 & - & Nest $(\mathrm{S}, \mathrm{W})$ & Nest $(S, W)$ \\
\hline Euchilotermes arcuata Silvestri, 1914 & Nest $(\mathrm{S}, \mathrm{W})$ & - & - \\
\hline Noditermes cristifrons (Wasmann, 1911) & Nest $(S, W)$ & Nest $(K, Q, S, W)$ & Nest $(S, W)$ \\
\hline Amitermes evuncifer (Silvestri, 1912) & Dead wood (S, W) & - & - \\
\hline Microcerotermes fuscotibialis (Sjöstedt, 1896) & Tree, arboreal nest $(\mathrm{S}, \mathrm{W})$ & Trees $(\mathrm{S}, \mathrm{W})$ & - \\
\hline Microcerotermes near parvulus (Sjöstedt, 1911) & - & - & Tree stump $(\mathrm{S}, \mathrm{W})$ \\
\hline Microcerotermes near solidus Silvestri, 1912 & Nest $(\mathrm{S}, \mathrm{W})$ & Dead wood $(S, W)$ & - \\
\hline Pericapritermes urgens Silvestri, 1914 & Nest $(\mathrm{S}, \mathrm{W})$ & - & Nest $(S, W)$ \\
\hline Promirotermes holmgreni (Silvestri, 1912) & - & Nest $(S, W)$ & $\begin{array}{l}\text { Stump, dead wood, nest } \\
(\mathrm{S}, \mathrm{W})\end{array}$ \\
\hline
\end{tabular}

.


Table 2. The termites species collected in different stations in Nyambai Forest Park

(Abbreviations: $\mathrm{K}=$ king; $\mathrm{Q}=$ queen; $\mathrm{S}=$ soldiers; $\mathrm{W}=$ workers)

\begin{tabular}{|c|c|c|c|}
\hline Nyambai Forest Park Species & Station 1 & Station 2 & Station 3 \\
\hline Ancistrotermes cavithorax (Sjöstedt, 1899) & $\begin{array}{c}\text { Tree, dead wood, litter (S, } \\
\text { W) }\end{array}$ & Dead wood $(\mathrm{S}, \mathrm{W})$ & Tree, dead wood $(\mathrm{S}, \mathrm{W})$ \\
\hline Ancistrotermes crucifer (Sjöstedt, 1897) & Tree $(S, W)$ & - & Stump, tree $(\mathrm{S}, \mathrm{W})$ \\
\hline Ancistrotermes guineensis (Silvestri, 1912) & Tree, dead wood $(\mathrm{S}, \mathrm{W})$ & $\begin{array}{c}\text { Tree, dead wood, liana, } \\
\text { soil }(\mathrm{S}, \mathrm{W})\end{array}$ & $\begin{array}{l}\text { Tree, dead wood, litter, soil } \\
(\mathrm{S}, \mathrm{W})\end{array}$ \\
\hline Macrotermes bellicosus (Smeathman, 1781) & $\begin{array}{c}\text { Nest, dead wood, litter (S, } \\
\text { W) }\end{array}$ & - & $\begin{array}{l}\text { Nest, stumps, tree, litter, } \\
\text { dead wood, soil (S, W) }\end{array}$ \\
\hline Microtermes grassei Ghidini, 1955 & - & - & Nest $(S, W)$ \\
\hline Microtermes lepidus Sjöstedt, 1924 & Tree, dead wood $(\mathrm{S}, \mathrm{W})$ & - & $\begin{array}{l}\text { Dead wood, soil, nest (S, } \\
\text { W) }\end{array}$ \\
\hline Odontotermes pauperans (Silvestri, 1912) & - & - & Dead wood, soil (S, W) \\
\hline Odontotermes sudanensis Sjöstedt, 1924 & $\begin{array}{c}\text { Tree, litter, dead wood (S, } \\
\text { W) }\end{array}$ & - & Nest, stump (S, W) \\
\hline Adaiphrotermes near cuniculator & - & - & Nest, soil (W) \\
\hline Aderitotermes near cavator & Soil (W) & Nest (W) & $\begin{array}{l}\text { Runways on tree, soil, nest } \\
\text { (W) }\end{array}$ \\
\hline Astalotermes near quietus & - & Soil (W) & Soil (W) \\
\hline Trinervitermes trinervius (Rambur, 1842) & Soil $(S, W)$ & - & - \\
\hline Basidentitermes potens Silvestri, 1914 & - & Soil $(S, W)$ & - \\
\hline
\end{tabular}


Cubitermes severus Silvestri, 1914

Cubitermes near proximatus Silvestri, 1914

Euchilotermes arcuata Silvestri, 1914

Noditermes cristifrons (Wasmann, 1911)

Amitermes evuncifer (Silvestri, 1912)

Pericapritermes urgens Silvestri, 1914

\begin{tabular}{ccl}
\hline Nest (S, W) & Nest (Q, S, W) & Nest (S, W) \\
\hline Nest (S, W) & - & Nest (S, W) \\
\hline- & - & Nest (S, W) \\
\hline Soil (S, W) & Nest (K, Q, S, W) & Nest (S, W) \\
\hline Dead wood (S, W) & Shrub (S, W) & Nest (S, W) \\
\hline- & Nest (S, W)
\end{tabular}

Promirotermes holmgreni (Silvestri, 1912) 


\section{Termites diversity in Tanji Bird Reserve}

At Tanji Bird Reserve, with 20 species, the species richness is less important than in the other two sites (table 3 ). The spatial distribution is also heterogeneous in this site as 15 species are recorded in the station 1, 12 species in the station 2 and 4 species in the station 3.

In terms of functional diversity, the fungus-growing termites (11 species) largely dominate the humivorous ( 5 species) and the xylophagous (1 species).

\section{New termite species recorded in The Gambia}

Among the 31 termite species recorded in Abuko Nature Reserve, Nyambai Forest Park and in Tanji Bird Reserve, 19 termite species are newly recorded from The Gambia.

For both subfamilies Coptotermitinae (Rhinotermitidae) and Apicotermitinae (Termitidae), one newly recorded species has been found, respectively Coptotermes intermedius and Astalotermes near quietus.

In the Macrotermitinae (Termitidae) the 8 newly recorded species from The Gambia are : Ancistrotermes cavithorax, Macrotermes bellicosus, Microtermes grassei, M. lepidus, M. subhyalinus, Odontotermes erraticus, O. pauperans and O. sudanensis.

The three new species of Cubiterminae (Termitidae) are Basidentitermes sp., Euchilotermes arcuata and Noditermes cristifrons.

Six species of Termitinae are new for Gambia: Amitermes evuncifer, Amitermes spinifer, Microcerotermes fuscotibialis, Microcerotermes near parvulus, Microcerotermes near solidus, Promirotermes holmgreni.

\section{Additionnal informations on some species}

Based on frequent confusion and misidentification in the West African Odontotermes and Cubitermes, we give some descriptive informations on Odontotermes erraticus, Cubitermes severus and Cubitermes near proximatus. Euchilotermes arcuata, a subspecies described by Silvestri, is elevated to the rank of species, taking into account the distinctive features used in the discrimination of species of the genus. Finally some informations are given on Basidentitermes sp. and Noditermes cristifrons. 
Table 3. The termites species collected in different stations in Tanji Bird Reserve

(Abbreviations: $\mathrm{S}=$ soldiers; $\mathrm{W}=$ workers)

\begin{tabular}{|c|c|c|c|}
\hline Tanji Bird Reserve Species & Station 1 & Station 2 & Station 3 \\
\hline Ancistrotermes cavithorax (Sjöstedt, 1899) & Stump, soil $(\mathrm{S}, \mathrm{W})$ & Dead wood $(S, W)$ & Nest, dead wood (S, W) \\
\hline Ancistrotermes crucifer (Sjöstedt, 1897) & Dead wood $(\mathrm{S}, \mathrm{W})$ & - & - \\
\hline Ancistrotermes guineensis (Silvestri, 1912) & Dead wood, soil $(\mathrm{S}, \mathrm{W})$ & $\begin{array}{c}\text { Litter, dead wood, tree (S, } \\
\text { W) }\end{array}$ & - \\
\hline Macrotermes bellicosus (Smeathman, 1781) & Tree, soil $(\mathrm{S}, \mathrm{W})$ & Litter, soil (S, W) & Nest, dead wood (S, W) \\
\hline Macrotermes subhyalinus (Rambur, 1842) & Dead wood in soil $(\mathrm{S}, \mathrm{W})$ & - & - \\
\hline Microtermes grassei Ghidini, 1955 & Soil (S, W) & - & - \\
\hline Microtermes lepidus Sjöstedt, 1924 & Dead wood $(\mathrm{S}, \mathrm{W})$ & - & - \\
\hline Microtermes subhyalinus Silvestri, 1914 & Dead wood $(\mathrm{S}, \mathrm{W})$ & Dead wood, soil (S, W) & - \\
\hline Odontotermes erraticus Grassé, 1944 & - & $\begin{array}{c}\text { Preys of Megaponera, soil } \\
(\mathrm{S}, \mathrm{W})\end{array}$ & - \\
\hline Odontotermes pauperans (Silvestri, 1912) & - & Nest, dead wood (S, W) & Soil (S, W) \\
\hline Odontotermes sudanensis Sjöstedt, 1924 & - & Nest, soil $(\mathrm{S}, \mathrm{W})$ & - \\
\hline
\end{tabular}


Astalotermes near quietus

Basidentitermes potens Silvestri, 1914

Cubitermes near proximatus Silvestri, 1914

Cubitermes severus Silvestri, 1914

Noditermes cristifrons (Wasmann, 1911)

Amitermes evuncifer (Silvestri, 1912)

Amitermes spinifer (Silvestri, 1914)

Microcerotermes fuscotibialis (Sjöstedt, 1896)

Microcerotermes near parvulus (Sjöstedt, 1911)

\begin{tabular}{ccc}
\hline $\begin{array}{c}\text { Soil, Nest (Pseudoecy), } \\
\text { runway on tree (W) }\end{array}$ & - & - \\
\hline Nest, soil (S, W) & - & - \\
\hline Nest, soil (S, W) & Nest (S, W) & Nest, soil (S, W) \\
\hline Nest (S, W) & Nest (S, W) & - \\
\hline Nest, stump (S, W) & Stump, dead wood (S, W) & - \\
\hline Tree (S, W) & Nest (S, W) & - \\
\hline Nest (S, W) & Tree (S, W) & \\
\hline
\end{tabular}


Odontotermes erraticus Grassé, 1944

The head of the soldier (figure 5) is yellow-orange in colour or dark-brown. The antennae are with 16 articles. The left mandible shows a marginal tooth. The two soldier head measurements are: head length $1.61 \mathrm{~mm}$ and $1.64 \mathrm{~mm}$, head width $1.27 \mathrm{~mm}$ and $1.28 \mathrm{~mm}$, left mandible length $1.10 \mathrm{~mm}$ and $1.15 \mathrm{~mm}$, hind tibia length $1.09 \mathrm{~mm}$.

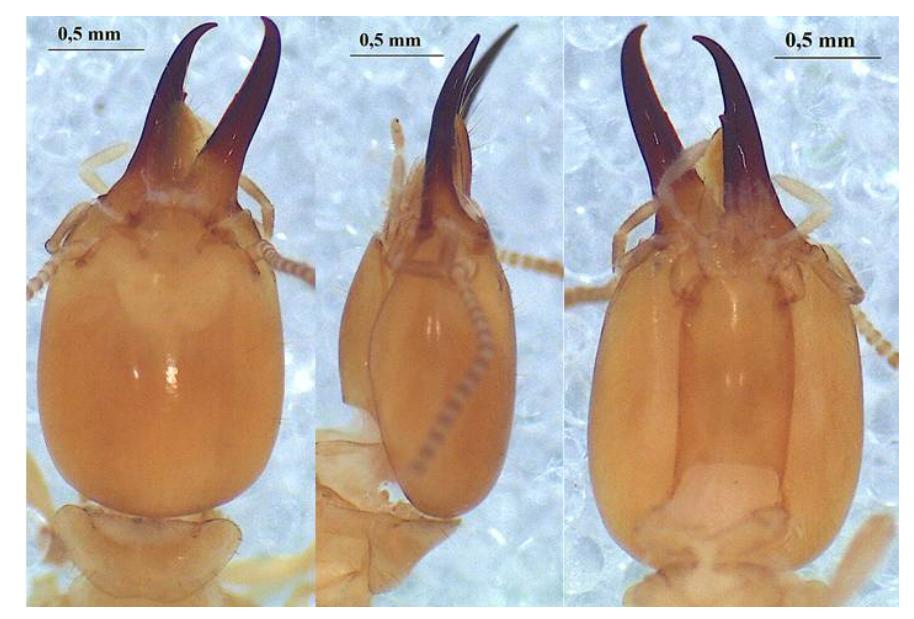

Figure 5. Head of of Odontotermes erraticus Grassé 1944 soldier in dorsal (left), profile (middle) and ventral (right) views

The large worker have 17 articles in their antennae whereas the small worker individuals have 16 articles in their antennae. Head measurements are shown in table 4 and table 5.

Table 4. Measurements (mm) of large workers of Odontotermes erraticus Grassé

\begin{tabular}{lccc}
\hline Worker & Range & Mean & Number \\
\hline Head length & $1.25-1.34$ & 1.29 & 5 \\
\hline Head width & $1.33-1.40$ & 1.36 & 5 \\
\hline Hind tibia length & $1.05-1.11$ & 1.08 & 4 \\
\hline
\end{tabular}

Table 5. Measurements ( $\mathrm{mm})$ of small workers of Odontotermes erraticus Grassé

\begin{tabular}{lccc}
\hline Worker & Range & Mean & Number \\
\hline Head length & $0.85-0.87$ & 0.86 & 3 \\
\hline Head width & $0.91-0.92$ & 0.91 & 3 \\
\hline Hind tibia length & $0.86-0.88$ & 0.87 & 3 \\
\hline
\end{tabular}

Cubitermes severus Silvestri, 1914 
It is a species characteristic by the shape (fig. 6) and the size (table 6) of its soldier. The table 7 shows the dimensions of workers. It is the largest size Cubitermes in the collection.

Table 6. Measurements (mm) of soldiers of Cubitermes severus Silvestri, 1914

\begin{tabular}{lccc}
\hline Soldier & Range & Mean & Number \\
\hline Head length & $2.87-3.08$ & 2.99 & 9 \\
\hline Head width & $1.96-2.11$ & 2.03 & 9 \\
\hline Length of left mandible & $1.98-2.03$ & 2.01 & 9 \\
\hline Hind tibia length & $1.57-1.69$ & 1.63 & 8 \\
\hline
\end{tabular}

Table 7. Size Measurements (mm) of workers of Cubitermes severus Silvestri, 1914

\begin{tabular}{lccc}
\hline Worker & Range & Mean & Number \\
\hline Head length & $1.11-1.19$ & 1.14 & 5 \\
\hline Head width & $1.19-1.24$ & 1.21 & 5 \\
\hline Hind tibia length & 1.25 & $1.29-1.27$ & 4 \\
\hline
\end{tabular}

Cubitermes severus has been collected both in nests without cap (fig. 7a) and in typical mushroom nests (fig. 7b). The column of the nest is much higher than that of Cubitermes near proximatus. This mound builder species occupies alone his nest or shares it with the inquilines Promirotermes holmgreni, Noditermes cristifrons and Pericapritermes urgens.

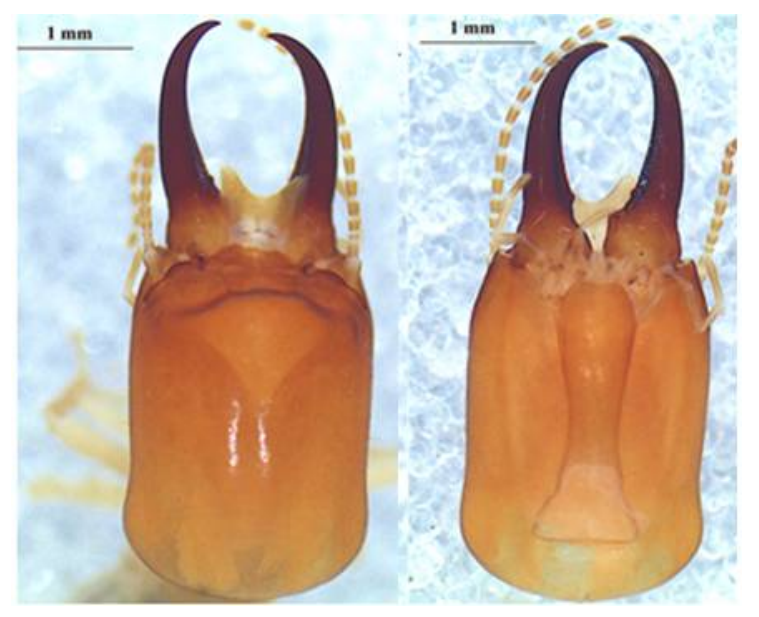

Figure 6. Head of Cubitermes severus Silvestri 1914 soldier in dorsal (left), profile (middle) and ventral (right) views 


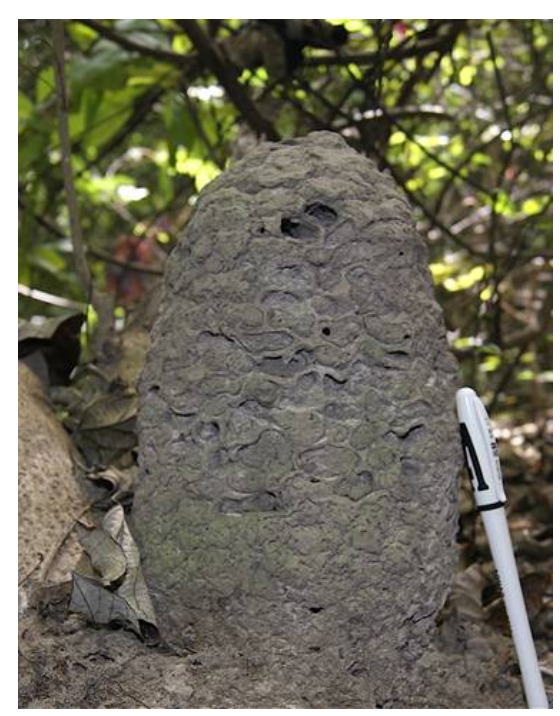

Figure 7a. Nest of Cubitermes severus Silvestri 1914 without cap

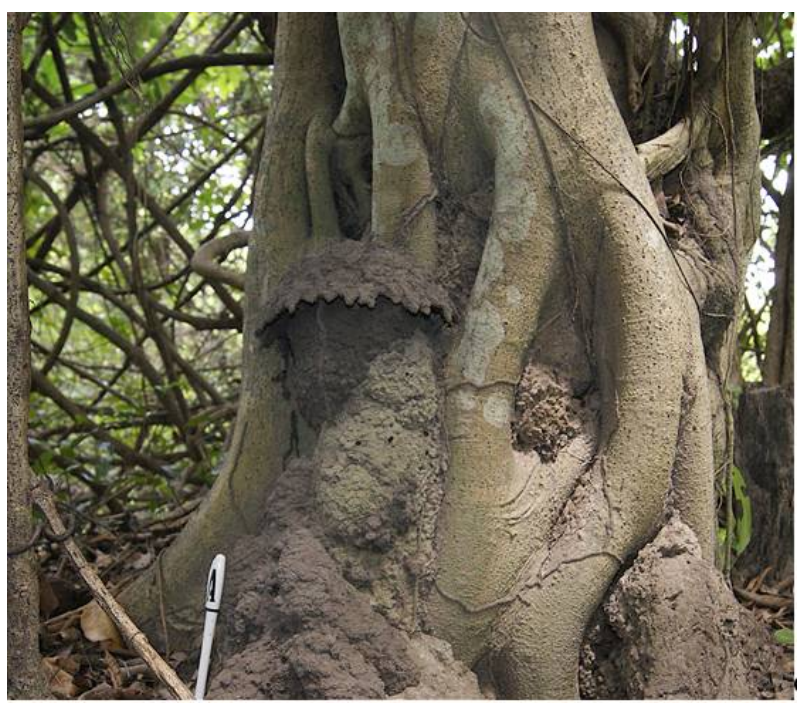

Figure 7b. Nest of Cubitermes severus Silvestri 1914 with cap

\section{Cubitermes near proximatus Silvestri, 1914}

The observation of the enteric valves of the workers of these Cubitermes shows their proximity to $C$. proximatus. However, based on the morphology, the color and the dimensions of the soldier's head, we divided them into two morphotypes.

Morphotype 1 of Cubitermes near proximatus

It is a species recognizable by the shape and the ochraceus colour of the head of its soldiers (fig. 8). The table 8 shows the dimensions of the soldier and the table 9 those of worker. 
Table 8. Measurements ( $\mathrm{mm}$ ) of soldiers of the morphotye 1 of Cubitermes near proximatus Silvestri, 1914

\begin{tabular}{lccc}
\hline Soldier & Range & Mean & Number \\
\hline Head length & $1.76-1.98$ & 1.89 & 8 \\
\hline Head width & $1.37-1.49$ & 1.43 & 8 \\
\hline Length of the left mandible & $1.44-1.50$ & 1.48 & 8 \\
\hline Hind tibia length & $1.14-1.16$ & 1.14 & 4
\end{tabular}

Table 9. Measurements ( $\mathrm{mm})$ of workers of the morphotype 1 of Cubitermes near proximatus Silvestri, 1914

\begin{tabular}{|c|c|c|c|}
\hline Worker & Range & Mean & Number \\
\hline Head length & $0.82-0.89$ & 0.85 & 4 \\
\hline Head width & $0.93-0.94$ & 0.93 & 4 \\
\hline Hind tibia length & $0.92-0.95$ & 0.94 & 3 \\
\hline
\end{tabular}

Figure 8. Head of morphotype 1 of Cubitermesnear proximaus Silvestri 1914 soldier in dorsal (left) and ventral (right) views

Morphotype 2 of Cubitermes near proximatus

The soldier of the morphotype 2 (fig. 9) is clearly larger (table 10). Morphologically, differencies are noted on the lateral margin of the head, which is less convergent, and the mandibles that are less curved in $C$. proximatus. The indentations at the base of the mandibles (ventral view of fig. 8 and fig. 9) are also distinctive features between the two morphotypes. 
Table 10. Measurements $(\mathrm{mm})$ of soldiers of the morphotype 2 of Cubitermes near proximatus Silvestri, 1914

\begin{tabular}{lccc}
\hline Soldier & Range & Mean & Number \\
\hline Head length & $2.05-2.19$ & 2.13 & 8 \\
\hline Head width & $1.50-1.65$ & 1.59 & 8 \\
\hline Length of left mandible & $1.60-1.70$ & 1.64 & 8 \\
\hline Hind tibia length & $1.24-1.32$ & 1.28 & 7 \\
\hline & & & \\
& & & \\
\end{tabular}

Figure 9. Head of Cubitermes proximatus Silvestri 1914 soldier in dorsal (left) and ventral (right) views

The measurements of the morphotype 2 workers are shown in the table 11 .

Table 11. Measurements ( $\mathrm{mm})$ of workers of of the morphotype 2 Cubitermes near proximatus Silvestri, 1914

\begin{tabular}{lccc}
\hline Worker & Range & Mean & Number \\
\hline Head length & $0.96-1.04$ & 1.04 & 7 \\
\hline Head width & $1.01-1.05$ & 1.03 & 7 \\
\hline Hind tibia length & $0.98-1.01$ & 1.00 & 7 \\
\hline
\end{tabular}

The mushroom nests of morphotype 2 are small in size (fig. 10). The column is often sufficiently developed to allow a clear distinction with the cap. The nests are occupied solely by the builber or shared with inquilines such as Allognathotermes hypogeus, Euchilotermes arcuata, Microtermes grassei and/or Promirotermes holmgreni infera. 


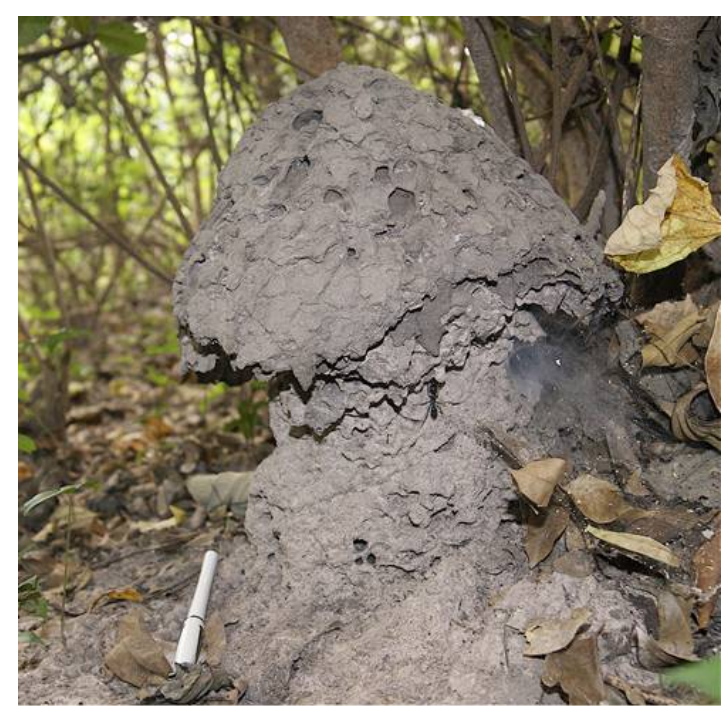

Figure 10. Mushroom nest of Cubitermes proximatus Silvestri, 1914

Euchilotermes arcuata Silvestri, 1914

The head of E. arcuata soldier (fig. 11) is distinctly rectangular in shape and yellowish in color with light brown mandibles. The mandibles are strongly curved. The labrum is long and wide with two apical large and rounded lobes. The measurements of the soldiers are noted in table 12 and those of the workers in the table 13.

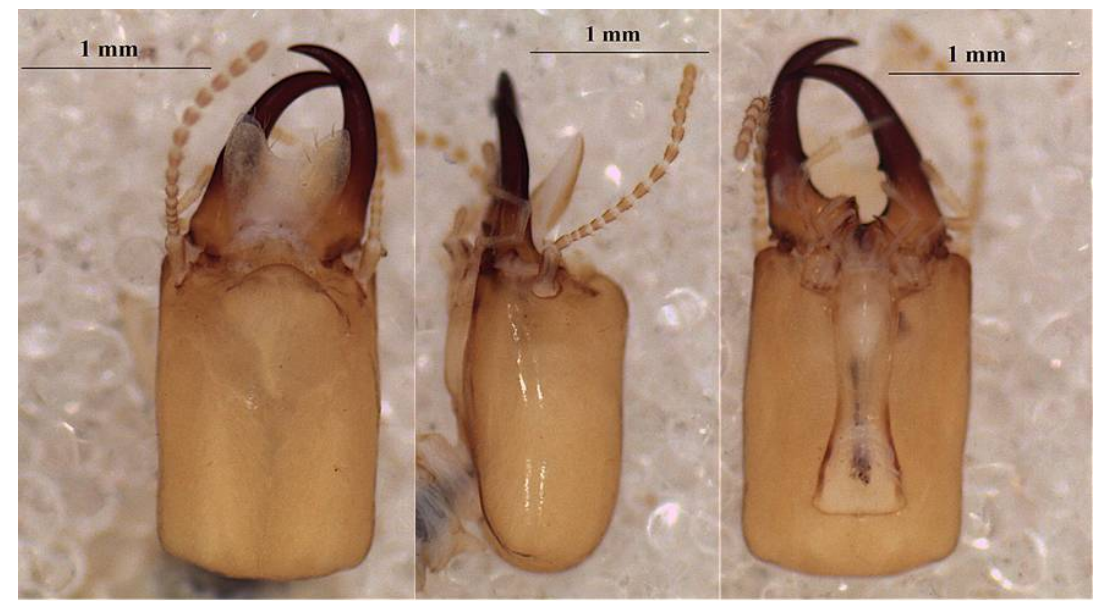

Figure 11. Head of Euchilotermes arcuata Silvestri 1914 soldier in dorsal (left), profile (middle) and ventral (right) views

Table 12. Measurements (mm) of soldiers of Euchilotermes arcuata Silvestri, 1914

\begin{tabular}{lccc}
\hline Soldier & Range & Mean & Number \\
\hline Head length & $1.76-1.85$ & 1.82 & 6 \\
\hline Head width & $1.16-1.24$ & 1.21 & 6 \\
\hline Length of left mandible & $1.15-1.19$ & 1.17 & 6 \\
\hline Hind tibia length & $0.89-0.97$ & 0.91 & 6 \\
\hline
\end{tabular}


Table 13. Measurements (mm) of workers of Euchilotermes arcuata Silvestri, 1914

\begin{tabular}{lccc}
\hline Worker individual & range & Mean & Number \\
\hline Head length & $0.75-0.84$ & 0.79 & 4 \\
\hline Head width & $0.81-0.88$ & 0.84 & 4 \\
\hline Hind tibia length & $0.77-0.84$ & 0.81 & 4 \\
\hline
\end{tabular}

\section{Basidentitermes sp.}

The specimens so designated seem different from all known species of the genus. However more specimens, particularly of soldiers, are needed before the description of a new species.

\section{Noditermes cristifrons (Wasmann, 1911)}

The measurements of soldiers of Noditermes cristifrons recorded in table 14 .

Table 14. Measurements ( $\mathrm{mm}$ ) of soldiers Noditermes cristifrons (Wasm.)

\begin{tabular}{llll}
\hline Soldier & Range & Mean & Number \\
\hline Head length & $1.16-1.32$ & 1.24 & 15 \\
\hline Head width & $1.00-1.10$ & 1.04 & 15 \\
\hline Length of left mandible & $1.30-1.46$ & 1.38 & 15 \\
\hline Hind tibia length & $0.76-0.82$ & 0.80 & 8 \\
\hline
\end{tabular}

The nests of Noditermes cristifrons (fig. 12), are free standing or backed to a tree which affects in this case the shape. However in both cases, the nest displays a scaly appearance. Noditermes cristifrons occupies alone its nest or shares it with Pericapritermes urgens. 


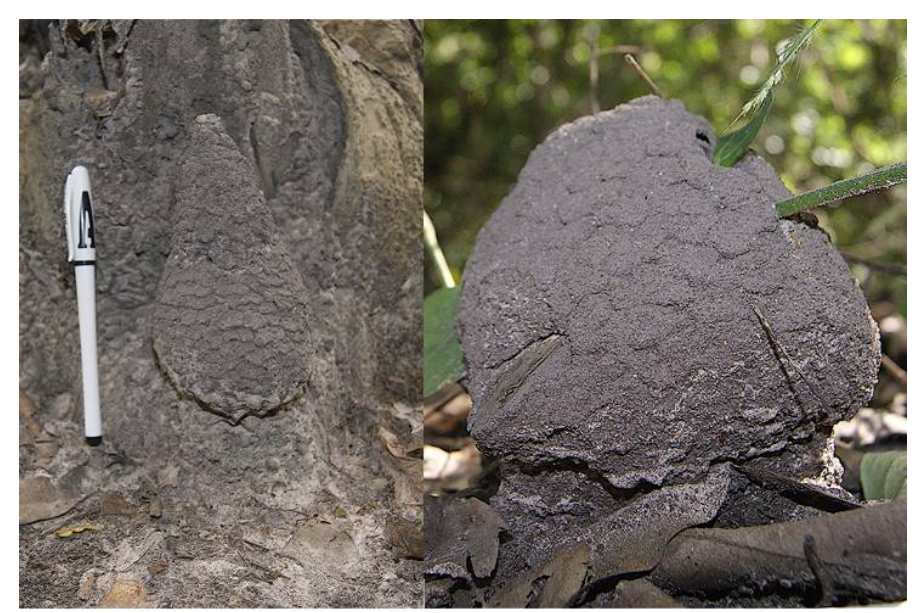

Figure 12. Noditermes cristifrons: tree trunk-backed nest (left); freely standing nest (right)

\section{DISCUSSION}

The compilation of the references on the termites of The Gambia gives for this country, 30 species. The present study has extended the number of termites species recorded from The Gambia to 46. On the overall 31 species that have been newly collected, nineteen (16) species are new for The Gambia of which one is probably new for science.

Of the thirty one (31) species recorded during this study, only the morphotype 2 of Cubitermes sp. near proximatus and Euchilotermes arcuata are not known in Senegal. The morphotype 1 of Cubitermes sp. near proximatus recorded in Senegal [22, 23] was identified as C. bilobatodes. Cubitermes severus exists in Casamance, Senegal, but has been cited by misidentification as C. fungifaber [23].

Odontotermes, described from Niger by Grassé [16], was indeed supposed to be restricted to Niger [5] Ndiaye [23] points out for the first time its occurrence in Senegal. As one of the newly added species to Gambia's termite, its presence is seemingly thoroughout West Africa. O. erraticus would be widespread in the Sudano-Sahelian zones of West Africa. Its presence was probably hidden by numerous misidentifications, particularly confusions with the species $O$. vulgaris and $O$. latericius of southern Africa. As Ruelle [24] pointed out, the genus Odontotermes is the most difficult of the Macrotermitinae.

The genus Euchilotermes, exclusively known in the Ethiopian region comprises four described species [5]. E. quadriceps described by Emerson [14] is known in Congo- 
Zaire (now RD Congo) and Malawi. E. umbraticola described by Williams [25, 26] is a species of East Africa (Kenya, Tanzania) [5]. Silvestri described E. tensus and the two varieties E. tensus var. acutidens and E. tensus var. Arcuata [13]. The variety acutidens has been elevated to the rank of species by Emerson [14] on the basis of the following differences: «mandibles more prolonged and curved at apex than with M. tensus, the teeth are smaller and sharper with a wider gula».

The comparison of E. tensus and E. arcuata shows significant differences:

- $\quad$ more fleshy labrum in E. arcuata;

- mandibles are curved at the middle in E. arcuata and straight in E. tensus;

- stronger marginal teeth at the base of the mandibles in arcuata;

- the shape of the indentation below the marginal teeth is different in the two species;

- upper side of the head, in profile view, is convex in E. arcuata and concave in $E$. tensus;

- mandibles and hind tibias are shorter in arcuata.

On the base of these differences, which are of the same order as those which have justified the elevation of the $E$. acutidens variety to the rank of species, we consider $E$. arcuata as a distinct species from E. tensus.

Thus, the five (5) species of Euchilotermes are:

1. Euchilotermes acutidens (Silvestri, 1914);

2. Euchilotermes arcuata (Silvestri, 1914) treated as a separate species in this paper.;

3. Euchilotermes quadriceps (Emerson 1928);

4. Euchilotermes tensus Silvestri, 1914 ;

5. Euchilotermes umbraticola (Williams, 1954). 
According to Krishna et al. [5], Microtermes hollandei Grassé is put in synonymy with M. lepidus Sjöstedt by Emerson (unpublished catalog). This synonymy is fully justified considering the perfect resemblance between the two species. Grassé [15], author of the original provisional description of $M$. hollandei, found himsel minor the differences between the two species and explained them by geographical distribution. However, it should be noted that the specimens used in the description of M. lepidus [27] and $M$. hollandei [15] both are from Dakar region (Senegal).

Microcerotermes fuscotibialis is easily distinguished by the morphology, the size and the ecology from M. solidus, M. parvus, and M. parvulus, which are referred to as small Microcerotermes [22]. The difficulties in the discrimination of these small Microcerotermes are the source of multiple misidentifications. Described from tropical Africa and cited from all African regions, M. parvulus was also recorded from Saudi Arabia [28]. This wide distribution can be explained by a strong plasticity of the species or due to misidentification, the most parsimonious hypothesis. As noted by several authors [29, 30, 22, 23], we believe that the revision of the African Microcerotermes is necessary.

ACKNOWLEDGMENT. This research work was funded by the West African Economic and Monetary Union (UEMOA). We are very grateful to Professor Guy Josens (Université Libre de Bruxelle) for his enlightened remarks on the identification of the Cubitermes species.

AUTHOR CONTRIBUTIONS. Conceptualization Abdoulaye Baila NDIAYE; Methodology, Abdoulaye Baila NDIAYE; Investigation, Abdoulaye Baila NDIAYE, Ebrima NJIE, Paul CORREA; Validation, Abdoulaye Baila NDIAYE, Ebrima NJIE, Paul CORREA; Formal Analysis, Abdoulaye Baila NDIAYE, Ebrima NJIE, Paul CORREA; Investigation, Abdoulaye Baila NDIAYE, Ebrima NJIE, Paul CORREA; Ressources, Abdoulaye Baila NDIAYE, Ebrima NJIE, Paul CORREA; Data curation, Abdoulaye Baila NDIAYE; Writing-Original Draft, Abdoulaye Baila NDIAYE; Writing-Review, Abdoulaye Baila NDIAYE, Ebrima NJIE, Paul CORREA; Visualization, Abdoulaye Baila NDIAYE; Supervision, Abdoulaye Baila NDIAYE; Project Administration, Abdoulaye Baila NDIAYE; Funding Acquisition, Abdoulaye Baila NDIAYE 


\section{REFERENCES}

1 Sands, W.A. New species and records of Nasutitermitinae (Isoptera: Termitidae) from Africa. Proceedings of the Royal Entomological Society of London 1968, 37, 163169.

2 Snyder, T.E. Catalog of the termites (Isoptera) of the World. Smithsonian Miscellaneous Collections 1949, 112, 1-493.

3 Sjöstedt, Y. (1925). Revision der Termiten Afrikas. 3. Monographie. Kungl Svenska Vetenska Akademiens handlingar 3 (1): 1-435.

4 Sjöstedt, Y. Revision der Termiten Afrikas. 3. Monographie. Kungliga Svenska vetenskapsakademiens handlingar, 1926, 3, 1-419.

5 Krishna, K.; Grimaldi, D.A.; Krishna, V. \& Engel, M.S. Treatise on the Isoptera of the World. 4. Termitidae (part one). Bulletin of the American Museum of Natural History 2013, 377, 1-2704.

6 Sands, W.A. The soldierless termites of Africa (Isoptera, Termitidae). Bulletin of the. British Museum (Natural History) Entomology, Supplement, 1972, 18, 1-244.

7 Sands, W.A. New genera and species of soil feeding termites (Isoptera: Termitidae) from African savannas. Journal of natural History 1995, 29, 1483-1515.

8 Sands, W.A. The Identification of Workers Castes of Termites Genera from Soils of Africa and the Middle East; Cab International: Wallington,UK, 1998, 500 pp.

9 Williams R.M.C.; Perez-Morales, J.V. The effect of group size on the survival and feeding economy of pseudoworkers of building damaging Cryptotermes spp. (lsoptera, Kalotermitidae). In: Jaisson P (ed) Social insects in the tropics. Presses de I'Université Paris Xll. Paris, 1983, Vol 2., 219-234.

10 Johnson, R.A. ; Lamb, R.W. ; Sands, W.A. ; Shittu M.O. ; Williams, R.M.C. ; Wood, T.G. A check list of Nigerian termites (Isoptera) with brief notes on their biology and distribution. Nigerian Field 1980, 45, 50-64. 
11 Jones, D.T.; Eggleton, P. Sampling termite assemblages in tropical forests: testing a rapid biodiversity assessment protocol. Journal of Applied Ecology 2000, 37, 191203.

12 Silvestri, F. Termitidi raccolti da L. Fea alla Guinea Portoghese e alla Isole S. Thomé, Annobon, Principe e Fernando Poo. Annali Museo Civico di Storia Naturale di Genova 1912, 45, 211-255.

13 Silvestri, F. Contribuzione alla conoscenza dei Termitidi e Termitophili dell'Africa occidentale. I. Termitidi. Bolletino del Laboratorio di Zoologia Generale e Agraria della R. Scuola Superiore d'Agricoltura 1914, 9, 1-146.

14 Emerson, A. E. Termites of the Belgian Congo and the Cameroon. Bulletin of the American Museum of Natural History 1928, 57, 212-222.

15 Grassé, P.-P. Recherches sur la systématique et la biologie des termites de l'Afrique occidentale française. Première partie: Protermitidae, Mesotermitidae et Metatermitidae (Termitinae). Annales de la Société Entomologique de France 1937, 106, 1-100.

16 Grassé, P.-P. Recherches sur la biologie des termites champignonnistes (Macrotermitinae). Annales des Sciences Naturelles 1944, 97-171.

17 Bouillon, A. ; Mathot, G. Quel est ce termite africain ? Zooleo 1965, 1, 1-115.

18 Roy-Noël, J. Le parc national du Niokolo-Koba. VIII. Isoptera. Mémoire de l'IFAN 1969, 84, 113-178.

19 Sands, W.A. A revision of the Termites subfamily Nasutitermitinae (Isoptera): Termitidae from the Ethiopian region. Bulletin of the. British Museum (Natural History) Entomology, Supplement, 1965, 4, 1-172.

20 Sands, W.A. The Termites Genus Amitermes in Africa and the Middle Natural Resources Institute Bulletin 1992, 51, 1-140.

21 Josens, G. Bilingual key of the West African Cubitermes soldiers and workers. Provisional version May 2018 produced during the Workshop organised by Pr. 
Judith Korb at the University of Freiburg from April 8 to April 12, 2018 : « Taxonomy of West African Termites : challenges and Prospects » 8 p.

22 Roy-Noël J. Recherches sur l'écologie des Isoptères de la presqu'île du Cap-Vert (Sénégal). Bulletin IFAN, série A, 1974, 26, 292-609.

23 Ndiaye, A.B. Contribution à la connaissance des Termites (Isoptera Brullé, 1832) du Sénégal: Systématique et Écologie. Partie I. Systématique. Thèse doctorat èsSciences, Université Ch. A. Diop, Dakar, Sénégal, 2014, 257 pp.

24 Ruelle, J.E. Isoptera. In Biogeography and Ecology of Southern Africa, Eds M. J. A. Werger and A. C. van Bruggen. Dr. W. Junk B. V. Publishers the Hague, 1978, pp. 748-762.

25 Williams, R.M.C. New Est African Termitinae (Isoptera: Termitidae). Proceedings of the Royal Entomoligical Society of London (B) 1954, 23, 215-227.

26 Williams, R.M.C. A correction Concerning two East African Termitinae (Isoptera: Termitidae). Proceedings of the Royal Entomoligical Society of London (B) 1962, $31,127-130$.

27 Sjöstedt, Y. Weitere Neuheiten von der afrikanischen Termitenfauna. Revue Zoologique Africaine 1924, 12, 495-497.

28 Faragalla, R.A.A.; Al Qhtani, M.H. The Urban termite fauna (Isoptera) of Jeddah City, Western Saudi Arabia. Life Science Journal 2013, 10, 1695-1701.

29 Noirot, Ch. Termites du centre et du sud-ouest de l'Angola récoltés par A. de Barros Machado. Publiçaões culturais de Companhia Diamantes de Angolas 1955, 27, 139-150.

30 Josens, G. Etudes biologique et écologique des Termites (Isoptera) de la savane de Lamto-Pakobo (Côte d'Ivoire). Thèse de doctorat ès Sciences, Université Libre de Bruxelles, 1972, $262 \mathrm{p}$. 